\title{
The Tonology of WH Questions in Luganda
}

\author{
Larry M. Hyman \\ University of California, Berkeley
}

Francis X. Katamba

University of Lancaster

The purpose of this paper is to show how WH questions interact with the complex tonal phenomena which we summarized and illustrated in Hyman \& Katamba (2010). As will be seen, WH questions have interesting syntactic and tonal properties of their own, including a WH-specific intonation. The paper is structured as follows: After an introduction in $§ 1$, we successively discuss nonsubject WH questions (§2), subject WH questions (§3), and clefted WH questions (§4). We then briefly present a tense which is specifically limited to WH questions (§5), and conclude with a brief summary in $\S 6$.

\section{Introduction}

According to Walusimbi (1996:65), there are three WH-question patterns in Luganda: "neutral”, “cleft”, and "pseudo-cleft”. The examples in (1) are his, to which we have added tone marks and morpheme glosses: ${ }^{1}$

(1)

a. b-óógér-á =kí

'what are they saying?' (lit. 'they say what?') they-say what

b. kì-kí kyè b-óógér-à 'what (it is that) they are saying?' what REL they-say

1 In (1) and subsequent examples we gloss the /-e/ morpheme used in non-subject relative clauses and clefts as REL (for relativizer) and the /-ee/ morpheme used in subject clefts and certain copular constructions as COP (see Hyman \& Katamba 1990 for discussion of both forms). As in many Bantu languages, these markers can be used in constructions with and without an overt head, e.g. èkìkópò kyè yàgúlà 'the cup (class 7) that he bought', kyè yàgúlà 'the one that he bought'. 
c. kyè b-óógér-à kyèè= kí 'what they are saying is what?' REL they-say COP what

In (1a) the WH enclitic =kí 'what' follows the verb, whereas a longer form kì-kí is clefted in (1b). The pseudocleft construction in (1c) contains both the nonsubject relativizer kyè as well as the (copular) subject cleft proclitic kyèè $=$ These and other WH constructions are the subject of this paper. Since we will be concerned with whether WH questions are tonally marked the same as main clauses or relative clauses, or are marked a third way, we shall begin with a brief summary of the Luganda tone system, recapitulating some of the major points from Hyman \& Katamba (2010).

As seen in (2), it is necessary to recognize three levels of representation in order to properly characterize the tonal system of Luganda, where the mora is the tone-bearing unit:

$\begin{array}{lccl} & \text { level of representation } & \text { tonal contrasts } & \text { description } \\ \text { a. } \quad \text { underlying input } & / \mathrm{H} /, \varnothing & \text { privative } \\ \text { b. intermediate } & \mathrm{H}, \mathrm{L}, \varnothing & \text { ternary } \\ \text { c. } & \text { surface output } & \mathrm{H}, \mathrm{L} & \text { binary }\end{array}$

As indicated, Luganda has an underlyingly privative contrast between $/ \mathrm{H} /$ and $\varnothing$ and a $\mathrm{H}$ vs. $\mathrm{L}$ contrast on the surface. (Underlyingly toneless moras will be realized $\mathrm{H}$ or $\mathrm{L}$ based on the various tone rules discussed in Hyman \& Katamba 2010). At an intermediate level corresponding roughly to the output of the lexical phonology, there is, however, a ternary contrast between $\mathrm{H}, \mathrm{L}$, and $\varnothing^{2}{ }^{2}$ This is due to two processes, Meeussen's Rule (MR) and L tone insertion (LTI), which introduce $\mathrm{L}$ tones. These are formalized in (3) along with the rule of $\mathrm{H}$ tone plateauing (HTP):

2 The three levels might be identified as morphophonemic, phonemic, and (systematic) phonetic, respectively. It can be noted that Luganda allows a HL falling tone on a prepausal short vowel and on a long vowel which is either penultimate or followed only by toneless moras. A marginal downstep may also occur when a $\mathrm{HL} \% \mathrm{H}$ sequence is simplified to $\mathrm{H}^{\downarrow}{ }^{\downarrow} \mathrm{H}$ at the boundary of two phonological phrases (\%). Luganda does not permit LH rising tones, whether on short or long vowels. 
(3) a. Meeussen's Rule (MR)

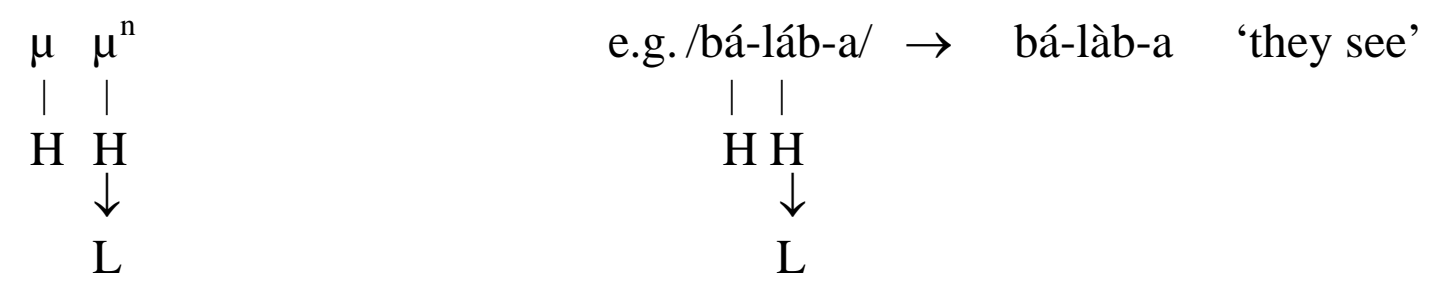

b. $\mathrm{H}$ tone plateauing (HTP)
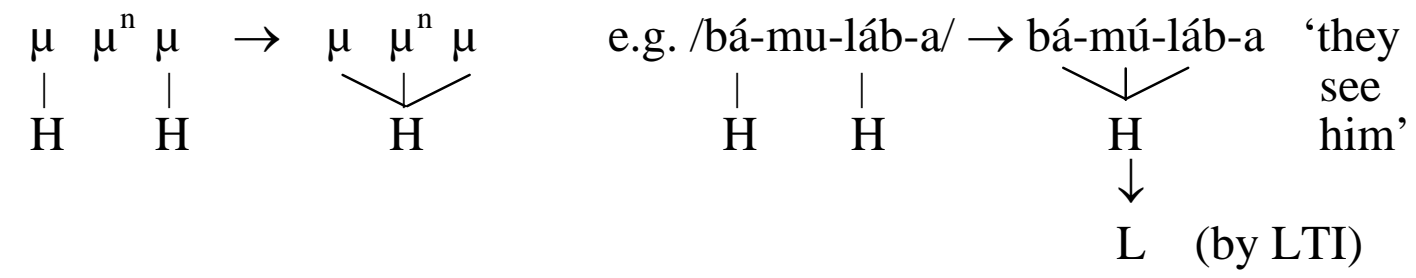

c. L tone insertion (LTI): $\varnothing \rightarrow \mathrm{L} / \ldots$ ]

d. /ki-sikí/ $\rightarrow$ ki-sikîi (by LTI) $\rightarrow$ ki-sikî 'log' (by FVS) $\mathrm{H} \quad \mathrm{HL}$ HL

As seen in (3a), an underlying / $\mathrm{H}-\mathrm{H} /$ sequence will be realized $\mathrm{H}-\mathrm{L}$. (A longer $/ \mathrm{H}+\mathrm{H}^{\mathrm{n}} /$ sequence will be realized $\mathrm{H}-\mathrm{L}^{\mathrm{n}}$, with all but the first $\mathrm{H}$ being lowered by MR.) In (3b) we see that when two Hs are separated by one or more toneless moras, a $\mathrm{H}$ tone plateau results. Finally, if after the application of MR and HTP a word has a $\mathrm{H}$ but no $\mathrm{L}$, a $\mathrm{L}$ is inserted after the $\mathrm{H}$. As a result, the form 'they see him' in (3b) surfaces as bá-mú-láb-à. In the derivation of ki-sikî 'log' in (3d), where neither MR nor HTP apply, LTI inserts a final L to create a final falling tone. As shown by Hyman \& Katamba (1990a), this results in vowel lengthening, which is preserved before an enclitic, e.g. ki-sikî =kí 'which log?', but which otherwise undergoes final vowel shortening (FVS). At the word level the first two moras of ki-sikî remain toneless. Whether they are realized $\mathrm{H}$ or $\mathrm{L}$ depends on the preceding tonal context, if any. (The word is realized kì-sìkî in isolation due to an initial \%L boundary tone.)

Moving on to the postlexical level, a rule of $\mathrm{L}$ tone deletion (LTD) deletes any Ls which occur between two $\mathrm{H}$ tones in what we refer to as the tone group (TG) domain:

(4) Post-lexical L tone deletion (LTD) : $\mathrm{L}^{\mathrm{n}} \rightarrow \varnothing /[\ldots \mathrm{H}-\mathrm{H} \ldots]_{\mathrm{TG}}$

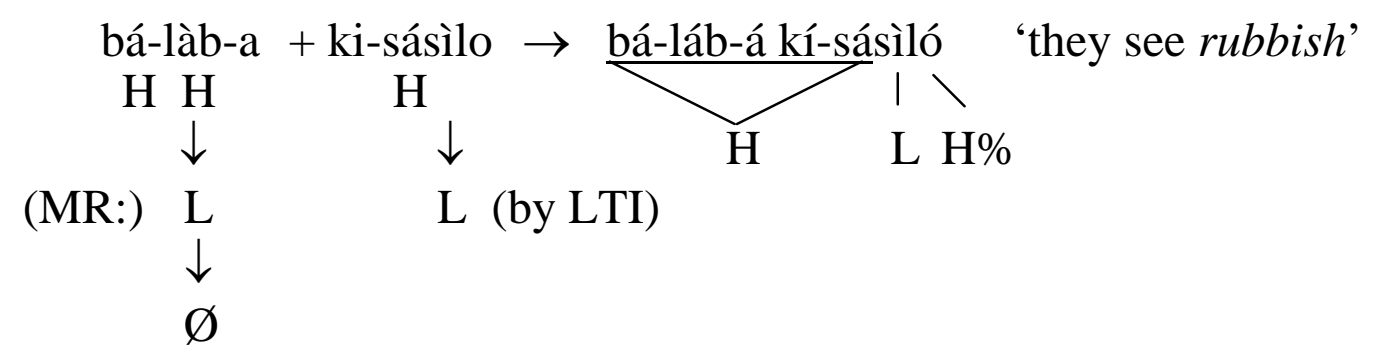


As indicated, MR first applies to /bá-láb-a/ to produce intermediate bá-làb-a. The resulting $\mathrm{L}$ is then deleted by LTD since it occurs between two Hs within the TG. The following noun /ki-sásilo/ undergoes LTI to become ki-sásìlo. As indicated, the final mora receives a $\mathrm{H}$ tone from the final $\mathrm{H} \%$ boundary tone.

Having established the major tonal properties that will be important for our study, we can now turn to the tonology of WH questions.

\section{Non-subject WH questions}

We begin with non-subject WH questions. Adopting Walusimbi's (1996) terminology, in "neutral" non-subject questions, the WH element occurs in a position immediately after the verb (IAV), generally reserved to mark focus. The verb has the same morphology and tonology as in regular main clauses:
a. bá-láb-á =ání
'who do they see?'
b. bá-láb-á =kí ( kí-kí)
'what do they see?
c. bá-mú-láb-á =ddí
'when do they see him?'
d. bá-mú-láb-á =wá
'where do they see him?'
e. bá-láb-á bá-méká
'how many (cl.2) do they see?'

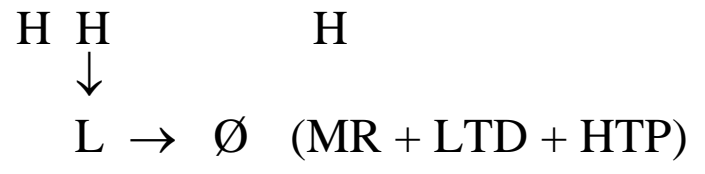

In the above examples, the WH element forms a TG with the verb exactly as seen earlier in (4), hence LTD and HTP apply to the lexical output of the verb bá-làb-a 'they see'. An interesting point to which we will return is that these markers condition LTD and HTP, hence have a /H/, but this $\mathrm{H}$ does not become HL by LTI (cf. bi-tabo bi-meká 'how many books?', where the preceding word is toneless). Although all the WH elements in all but (5e) are enclitics, the first two have corresponding plural forms which are independent words:

(6) a. bá-láb-á bá-ání 'who (pl.) do they see?’

b. bá-láb-á bí-kí 'what (pl.) do they see?'

The singular and plural pairs are easily identified as class $1 / 2$ ('who') and class 7/8 ('what'), the latter singular having two forms: =kí and ki-kí.

As mentioned, the IAV represents a position identified with focus marking (Hyman \& Katamba 1993). By IAV is meant the position after the verb and any non-WH enclitcs $\left(\mathrm{P}_{2}=\right.$ the general past $)$ : 
(7) a. y-à-gí-téék-á =múù =kí ' 'what did he put in it?' he-P2-it-put in what

b. y-à-téék-á =kí mù-yô $\quad$ (= marginal, but much better than (7c)) he-P 2 -put what in-it

c. *y-à-téék-á mú $=$ yó $={ }^{\downarrow}$ kí he- $\mathrm{P}_{2}$-put in it what

In (7a) we see that =kí follows the locative enclitic =múù, whereas it must precede non-enclitic mù-yô in (7b). Since the WH element in (7c) is preceded by a full word, it is ungrammatical-and would also be so with the longer WH forms ki-kí/bi-kí. The sentences in (8) also show that a full word locative follows a WH element, while a locative enclitic precedes:

(8) a. w-à-gúl-á =kí è-káámpálâ 'what did you buy in Kampala?' you-P2-buy what at-Kampala

b. w-à-gúl-á =yóò =kí 'what did you buy there?' you- $\mathrm{P}_{2}$-buy there what

The sentences in (9) show that the IAV includes WH elements which are expressed via a noun phrase or conjugated verb -tyá 'to how':

(9) a. y-à-fúúmb-à mù= n-gélí =kí ò-mù-púùngá 'how did he cook rice?' he- $\mathrm{P}_{2}$-cook in 9-kind which 3-rice ('in what manner'?)

b. *y-à-fúúmbà ò-mù-púùngà mù= ngérí =kí

c. bá-á-fúúmb-á bá-tyá òmùpúùngá 'how did they cook rice?' they-P2-cook they-how 3-rice

d. *bá-á-fúúmbà òmùpúùngà bá-tyá

(9b) shows that even a full NP WH expression must be in the IAV position, and similarly for the verbal WH -tyá 'to how' which agrees with the preceding subject (cf. y-a-fúúmb-á á-tyá òmùpúùngá 'how did he cook rice?).

Perhaps because each would have to be in IAV position, multiple postverbal WH are not permitted:

(10) a. *y-à-w-á =ání = ${ }^{\downarrow}$ kí (intended: 'who did he give what?’) *y-à-wá =kí =àní

b. *y-à-láb-á =ání = ${ }^{\downarrow}$ ddí (intended: 'who did he see when?') *y-à-láb-á =ddí =àní

On the other hand, WH words can co-occur in echo questions if one is preverbal, either as subject-WH, as in (11a), or clefted, as in (9b,c) (cf. §3, §4 below): 
(11) a. àní è-y-à-láb-á =kí who AUG-he- $\mathrm{P}_{2}$-see what

b. àní gwè y-à-w-á =kí 'WHO did he give WHAT?' who REL he- $\mathrm{P}_{2}$-give what

c. àní gwè y-à-láb-á =ddí who REL he- $\mathrm{P}_{2}$-see when
'WHO SaW WHAT?'

'WHO did he see WHEN?'

Although this needs to be studied more in detail, some cases have been observed where WH elements appear post-IAV in an echo question:
a. $\quad$-a-sóm-á =kí ' ná-bò
he- $\mathrm{P}_{2}$-read what with-them
b. y-a-sóm-á ná-bò kí he-P $\mathrm{P}_{2}$-read with-them what
c. y-à-fúúmb-íl-á =kí ò-mw-áàná 'what did he cook for the child?' he-P $P_{2}$-cook-APPL what child
d. y-à-fúúmb-ìl-à ò-mw-áànà kí he cooked WHAT for the child?' he-P $\mathrm{P}_{2}$-cook-APPL child what
'what did he read with them'?
'he read with them WHAT?'

In addition, WH elements are not attracted to IAV in relative clauses, which are necessarily echo questions:
(13) a. è-y-à-fúúmb-ìl-à ò-mw-áànà kí AUG-he-P2-cook-APPL child what
'the one who cooked WHAT
for the child?'
b. *è-y-à-fúúmb-íl-á = kí ò-mw-áàná AUG-he-P2-cook-APPL what child

As mentioned in $\S 1$, enclitic status is determined based on whether the $\mathrm{WH}$ element preserves preceding vowel length:
(14) a. y-à-ly-áá =kí ' what did he eat?'
b. y-à-ly-á kí-kí 'what did he eat?' he- $\mathrm{P}_{2}$-eat what

In (14a), the long vowel of -ly-áá is is derived from underlying /lí-a/ via gliding and compensatory lengthening (Tucker 1962, Katamba 1974, Clements 1986). As seen, the length is preserved before the enclitic =kí 'what', but not by the full word form ki-kí in (14b) (cf. y-à-lyá bí-kí 'what (pl.) did he eat?’). In actual fact it is only =kí 'what' and =wá' where' which allow us to establish that these are phonological enclitics. This is because the /a/ of =aní fuses with a preceding vowel, automatically producing a long vowel, while the geminate consonant of =ddí 'when' automatically conditions vowel shortening. Still, we can generalize 
that all of these short $\mathrm{WH}$ forms are enclitics, drawn as they are to the IAV position.

The main phonological issue we must address is how to account for the final $\mathrm{H}$ on =ání 'who', =kí 'what', =ddí 'when', =wá 'where'. Recall from (5) that these morphemes must have an underlying / $\mathrm{H} /$ because they trigger LTD and HTP. However, if they end /H/, why don't they undergo LTI to become HL when final, as expected. Thus compare the two sentences in (15).

(15) a. y-à-ly-áá =kí 'what did he eat?'

b. y-à-ly-áá =kô 'he ate a little'

In both cases the verb stem /-lí-a/ becomes -lí-à by LTI. The output of the lexical phonology is thus $y$-à-ly-áà, which then undergoes LTD and HTP before the $\mathrm{H}$ tone enclitics. As also seen, /=kó/ 'a little' undergoes LTI (becoming =kóò, then =kô by FVS), while /=kí/ does not. The question is why not?

First we note that final $\mathrm{H}$ of $\mathrm{WH}$ enclitics cannot be attributed to the $\mathrm{H} \%$ boundary tone. As seen in (16a), $\mathrm{H} \%$ links to all but the first of a sequence of toneless moras:

\begin{tabular}{|c|c|c|c|c|c|}
\hline \multirow{5}{*}{ a. } & \# syllables & underlying & $\% L$ without $H \%$ & $\% L$ with $H \%$ & \\
\hline & monosyllabic & /ki-de/ & kì-dè & kì-dé & 'bell' \\
\hline & bisyllabic & /ki-tabo/ & kì-tàbò & kì-tábó & 'book' \\
\hline & trisyllabic & /ki-lagilo/ & kì-làgìlò & kì-lágíló & 'command' \\
\hline & quadrisyllabic & /ki-sanilizo/ & kì-sànìlìzò & kì-sánílízó & ‘comb’ \\
\hline \multirow[t]{3}{*}{ b. } & bisyllabic & /ki-jíiko/ & kì-jîikò & kì-jîilkó & ‘spoon’ \\
\hline & trisyllabic & /ki-sásilo/ & kì-sásìlò & kìsásìló & 'rubbish' \\
\hline & quadrisyllabic & /ki-bónelezo/ & kì-bónèlèzò & kìbónèlézó & 'punishment' \\
\hline c. & bisyllabic & /ki-kópo/ & kì-kópò & $*$ & ‘cup’ \\
\hline \multirow[t]{2}{*}{ d. } & monosyllabic & /ki-bé/ & kì-bê & * & ‘jackal' \\
\hline & bisyllabic & /ki-sikí/ & ki-sikî & $*$ & 'log' \\
\hline
\end{tabular}

(16b) shows that $\mathrm{H} \%$ can link to the final mora of a word with a /H/, but not if the word ends H-L, as in (16c). Finally, (16d) shows that H\% fails to link if the word ends HL. Forms such as *kì-kópó, *kì-bé, and *kì-síkí are thus ungrammatical. It is thus clear that the final $\mathrm{H}$ of $\mathrm{WH}$ elements cannot be related to $\mathrm{H} \%$.

The final $\mathrm{H}$ of =aní, =kí etc. also cannot be attributed to yes-no question intonation, which Stevick (1969:27) describes as follows:

If the last word has a high tone, then this intonation is realized as rise in pitch followed by fall in pitch, beginning with the last tonic syllable. If the last tonic mora happens to 
be in the final syllable, then this rise-fall is very rapid, but it is all there. If the final word has no tonic moras, then the final syllable is extremely low in pitch.

In the following transcriptions, S stands for "superhigh" tone (Hyman 1990:123):

(17) a. tu-ba-gulilil-a $\rightarrow$ tú-bä-gùlìlìl-à 'are we bribing them?' $\mathrm{H} \quad \mathrm{L} \quad \mathrm{H} \quad \mathrm{S} \quad \mathrm{L}$

b. a-ba-gulilil-a $\rightarrow$ à-bà-gùlìlìl-à 'is he bribing them?' $\mathrm{L}$

Since normal yes-no question intonation ends in a low pitch, it is clearly unrelated to the final $\mathrm{H}$ of $\mathrm{WH}$ elements. Instead, Stevick's solution is to propose a separate "other question" (= WH) intonation:

In these questions, a final tonic syllable which with [statement] intonation would have $\wedge$ is pronounced with high level pitch, phonetically identical with '.

His example is ò-kól-á =kí 'what are you doing?', where the verb is underlyingly /o-kól-a/. About this form he adds (Stevick 1967:27):

Thus, I have recorded no tonetic difference between this question and the citation form of a noun with four short syllables: òmúlímú 'work'.

There seem to be two approaches to the problem. First, we could block LTI on WH elements, thereby making /=aní/, /=kí/ etc. exceptions to LTI. As a result, their underlying $/ \mathrm{H} /$ would remain $\mathrm{H}$ in final position. The second approach, following Stevick, is to derive the expected HL by LTI, but introduce an intonation which deletes the L of the HL on WH elements when they occur in final position. Evidence for this second approach is seen from the fact that $\mathrm{WH}$ elements sometimes do undergo LTI when not in final position: although more frequently pronounced $\mathrm{H}$, they can be realized $\mathrm{HL}$ if emphasized or followed by pause. Thus compare the following pairs of sentences:

(18) a. y-à-búúzá bá-ání à-bá-á-gw-à y-à-búúz-á bá-ánî à-bá-á-gw-à

b. y-à-lówòòz-à àní gwè tw-áá-làb-à y-à-lówòòz-à ànî gwè tw-áá-làb-à

c. sí-mányí wá gyè bà-bì-bàl-íl-à sí-mányí wâ gyè bà-bì-bàl-íl-à

d. sí-mányí ddí wè bà-bì-bàl-íl-à sí-mányí ddî wè bà-bì-bàl-íl-à 'who (pl.) did he ask that fell?'

(i.e. 'who that fell did he ask?')

'he wondered who we saw'

'I don't know where they count them'

'I don't know when they count them' 
Further evidence that non-final WH elements undergo LTI is seen in sentences such as those in (19), where the following input tone is $\mathrm{H}$ :

(19) a. àní ${ }^{\downarrow}$ y-á-gú-ddè 'who fell?' (recent past)

b. y-a-wá =kí ' Kígùndú 'what did he give Kigundu?' $\begin{array}{llllll}\mathrm{H} & \mathrm{H} & \mathrm{L} & \mathrm{H} & \mathrm{L} & \mathrm{H} \%\end{array}$

After /aní/ and /=kí/ become anî and =kî by LTI, their HL undergoes contour simplification, delinking the $\mathrm{L}$, which produces a following downstepped ${ }^{\downarrow} \mathrm{H}$. It seems that an A $\rightarrow$ B $\rightarrow$ A "Duke of York" derivation is motivated:

$$
\begin{aligned}
& \text { underlying LTI + V-length FVS "WH-intonation" } \\
& \text { /a-gul-a =kí/ } \rightarrow \text { a-gul-a =kîi } \rightarrow \text { a-gul-a =kî } \rightarrow \text { a-gul-a =kí } \\
& \mathrm{H} \quad \mathrm{HL} \quad \mathrm{HL} \quad \mathrm{H}
\end{aligned}
$$

We thus propose that the $\mathrm{HL}$ of a WH element obligatorily becomes $\mathrm{H}$ finally, as it usually does in non-final position, perhaps by L-delinking. It is important to note that only the WH element is so affected. A final HL to its right will remain HL:

(21) a. y-à-w-á =kí Kàtààmbâ ' 'what did he give Katamba?'

b. w-à-gúl-á =kí è-káámpálâ 'what did you buy in Kampala?'

The same final H realization is found in the noun phrase with =kí ' which':

(22) a. y-a-láb-à bi-kópò =kí ' 'which cups did he see?'

b. bá-á-kúb-á mwáánà =kí ' 'which child did they beat?'

As seen in the above examples, the noun obligatorily lacks an augment before =kí (*e-bi-kópò =kí, *o-mwáánà =kí). Since it also does not form a TG with $=k i ́$, LTD does not apply. As seen in (23) =kí tends to immediately follow the noun, from which it can be separated only by a possessive pronoun:

$$
N=k i ́+\text { modifier } \quad N+\text { modifier }=k i ́
$$

poss. bì-kópò =kí è-byáàngé bì-kópò =byààngè =kí 'which cups of mine?

adj. bì-kópò =kí è-bì-nénè ?*bì-kópò bì-nénè =kí 'which big cups?'

num. bì-kópò =kí è-bí-sàtú ?*bì-kópò bì-sátù =kí 'which three cups?' 
Not surprisingly, when modifying a noun phrase, -aní 'whose' also ends $\mathrm{H}$, as does -meká 'how many':

(24) a. à-gúl-á bí-kópó byáání 'whose cups is he buying?'

b. à-gúl-á é-bí-kópò bì-mèká 'how many cups is he buying?'

While most non-subject WH elements occur in the IAV position, there are different ways of forming 'why' questions, some of which involve WH elements in non-IAV position. One way is to use =kí with an applicativized verb. (25a) thus literally means 'he cooked rice for what?':

(25) a. y-a-fúúmb-íl-á =kí ò-mù-púùngá 'why did he cook rice?' he-P2-cook-appl what 3.rice

b. Iwáá=kí y-à-fúúmbà ò-mù-púùngá 'why did he cook rice?' for-what he- $\mathrm{P}_{2}$-cook 3.rice

c. *y-a-fúúmbà lwáá=kí ò-mù-púùngá

d. *y-a-fúúmbà ò-mù-púùngà lwáá=kí
e. y-á-jj-à lwàà= n-sóóngá =kí 'he came for what reason?' he-P $\mathrm{P}_{2}$-come account.of reason what

f. n-sóóngá =kí è-y-à-mù-léèt-á ' 'what reason brought him?' account.of what AUG-he-P2-him-bring

Another way of asking a 'why' question involves fronting the class 11 connective (genitive) lwáá = (from /lú-a/) + =kí. (25b) thus literally means '(on account) of what he cooked rice?'. The sentences in (25c,d) show that lwáá=kí cannot occur in IAV or post-IAV position. On the other hand, (25e) shows that a fuller expression involving the toneless noun $n$-soonga 'reason' can occur in the IAV position. When it is fronted, as in (25f), a relative clause form is used, hence with the literal meaning 'it's which reason that brought him' (i.e. that made him come).

With the above established we can now consider the ways of asking a subject WH question.

\section{Subject WH questions}

As seen in (26), subject WH questions require the WH element to precede the verb, which is often relativized:

3 In (24a) the underlying representation of class 8 byaaní is /bi-a-aní/, literally 'those of whom'. As in the case of possessives do in general, it forms a TG with the preceding noun /bi-kópo/ 'cups', and both LTD and HTP apply. 
(26) a. àní y-à-gw-â

'who fell?'

who he- $\mathrm{P}_{2}$-fall

b. àní è-y-à-gw-â 'who (is it) that fell?'

who AUG-he- $\mathrm{P}_{2}$-fall

c. bà-àní à-bá-gééndà 'who (pl.) is going? (Walusimbi 1996:67)

2-who AUG-he-P $\mathrm{P}_{2}$-fall

d. kì-kí è-kí-kú-lúm-à 'what is biting/hurting you?'

7-what AUG-it-you-bite

Further examples are provided in (27).

(27) a. kì-kí è-ky-áá-mú-fúúmb-ìs-à òmùpúùngà? ' 'what made him cook the 7-what AUG-it-P2-him-cook-CAUS rice rice' = 'why?'

b. mu-púúngà =kí ò-gw-áá-fúúmb-ìbw-à ' which rice was cooked? rice which AUG-it-P2-cook-PASSIVE

These sentences might better be translated 'what is it/it's what that made him cook rice' and 'it's which rice/which rice is it that was cooked?'. As elsewhere in the grammar, the augment marks an NP, but is absent when a postverbal NP occurs within the scope of negation or narrow focus (Hyman \& Katamba 1993). ${ }^{4}$

Although we will not go into detail here, relative verb forms have their own morphology and tonology. One morphological difference concerns the shape and placement of negative morphemes: In main clauses te- precedes the subject marker, while in relative clauses -ta- follows:

(28) a. tè-bá-á-làb-à Kàtààmbâ

'they didn’t see Katamba' NEG-they-P 2 -see Katamba

b. bà-àní à-bá-tá-á-làb-à Kàtààmbâ 'who pl. didn’t see Katamba?' 2-who AUG-they-NEG-P2-see Katamba

Since the subject relative verb begins an NP, it too can occur both with and without an augment:

(29) a. à-bà-kázì à̀-b-áá-làb-à è-bì-kópò 'the women who saw the cups' \%L $\quad \mathrm{HL} \quad \mathrm{H} \quad \mathrm{L} \mathrm{L} \quad \mathrm{H} \mathrm{L}$

b. a-ba-kázì à-bá-tá-á-làb-à bì-kópò 'the women who didn’t see \%L $\quad \mathrm{HL} \quad \mathrm{H} \quad \mathrm{HL} \quad \mathrm{L} \quad \mathrm{H} \mathrm{L} \quad$ the cups'

4 In Luganda when a sentence begins with a noun without augment, an underlying null focus marker (or copula) is assumed; cf. ò-mù-púùngá 'rice' vs. mù-púùngá 'it’s rice'. 
c. t-á-mányí bà-kázì b-áá-láb-á bí-kópò he doesn’t know the women

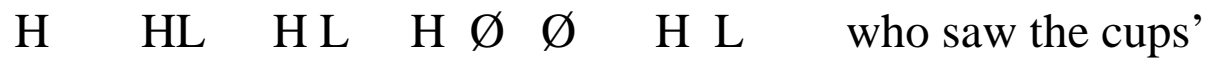

d. à-mànyí bá-kázì b-áá-láb-á bí-kópò 'he knows the women who $\mathrm{H} \varnothing \quad \mathrm{HL} \quad \mathrm{H} \quad \varnothing \quad \varnothing \quad \mathrm{H} \mathrm{L}$ saw the cups'

In (29a) the augment appears on the relativized verb and its object. On the other hand, the augment is missing on the object in (29b), since the relativized verb is in the negative. In (29c) the negation begins with the main verb and thus conditions the absence of an augment on every word that follows, including the relativized verb. The same is observed in (29d), where the absence of augments is conditioned by narrow focus on the object. These last two examples amply demonstrate that the augment does not specifically mark the subject relative, as sometimes mistakenly assumed.

\section{Clefted WH questions}

The third way to form a WH-question is by clefting. As seen in (30a,b), object WH elements can be clefted with the /-e/ marker used also in non-subject relative clauses, as in (30c).

(32) a. àní gwè bá-làb-á who REL they-see

b. kí kyè bá-làb-á what REL they-see

c. ̀̀-mù-kázì gwè bá-làb-á è-kì-kópò kyè bá-làb-á 'who do they see?' ('it's who that they see?')

(cf. (5a))

'what do they see?' ('it's what that they see?)

(cf. (5b))

'the woman that they see'

'the cup that they see'

However, subject- and adjunct-WH elements cannot be clefted in a direct question (cf. Walusimbi 1996:67, 71):
a. *àní yèè= y-à-gw-â
(intended: 'it's who that fell')
b. *kí kyè= ky-áá-gw-à
(intended: 'it's what that fell')
c. *wá gyè= bá-géénd-à
(intended: 'it's where that they are going?')
d. *ddí lwè= bá-géénd-à
(intended: 'it's when that they are going?')

However, /-e/ can be used with all WH elements except subject WH in embedded WH questions:

(34) a. m̀-mànyí ání gwè bá-làb-á

b. ̀̀-mànyí =kí kyè bá-làb-á

c. m̀̀-mànyí = wá gyè bá-gééndà
'I know who (that) they see'

'I know what (that) they see'

'I know where (that) they are going' 

d. ̀̀-mànyí =ddí lwè bá-gééndà
'I know when (that) they are going'
e. *mò-mànyí =ání yèè y-à-gw-â
'I know who (that) fell'
f. ì̀-mànyí =ání è-yà-gw-â
'I know who fell'

Non-subject clefted WH questions have the same morphology and tonology as relative clauses. However, a clefted answer to a WH question undergoes a left-edge $\mathrm{H}$ tone reduction (HTR) process which the $\mathrm{WH}$ question cannot (Hyman \& Katamba 2010). This can be observed in the following questionanswer pairs:

(35) a. Q: àní gwè bá-bál-íl-à è-bì-kópò

A: mwáánà gwè bà-bì-bàl-íl-à child REL they-them-count-APPL

b. Q: bì-kí byè bá-bál-íl-à ò-mwáàná 8-what REL they-count-APPL child

A: bì-kópò byè bà-mù-bàl-íl-à cups REL they-him-count-APPL 'who are they counting cups for?' (*bà-bàl-íl-à)

'it's the child they are counting them for'

'what (pl.) are they counting for the child?' (*bà-bàl-íl-à)

'it's the cups that they are counting for him'

As indicated by the underlining in (35), in non-WH non-subject clefts, HTR lowers a sequence of $\mathrm{Hs}$ to $\mathrm{L}$ at the beginning of the verb (see below for subject clefts). The result is a rather unique tonal property not found elsewhere in the grammar.

Although we have said that adjunct WH elements cannot be clefted, their answers can be. As now expected, the verb undergoes HTR:

(36) a. Q: bá-mú-bál-íl-á =wá è-bì-kópò they-him-count-APPL where cups

A: wànò wè bà-bì-mù-bàl-íl-à here REL they-them-him-count-APPL

b. Q: bá-mú-bál-íl-á =ddí è-bì-kópò they-him-count-APPL when cups

A: kààkátì bwè bà-bì-mù-bàl--íl-à now REL they-them-him-count-APPL 'where are they counting cups for him?'( *bà-mù-bàl-íl-à)

'it's here that they are counting them for him'

'when are they counting cups for him?'( 'bà-mù-bàl-íl-à)

'it's now that they are counting them for him'

The HTR difference between WH questions and their answers is reminiscent of English, where the WH element, although the focus of the sentence, does not receive the main phrasal stress: ${ }^{5}$

5 WHO is counting the cups? would be an exclamation expressing doubt, e.g. following an assertion like they are counting the cups. 
(37) a. Q: who is counting the cúPs?

A: the CHILD is counting the cups

b. Q: what is it they are cóunTing?

A: it's CÚPS they are counting

Similar to adjuncts, although a subject WH element cannot be clefted, its answer can be:

(38) a. Q: bà-àní à-bá-mú-bál-íl-à è-bì-kópò who AUG-they-him-count-APPL cups

A: bá-ánà bèè= bá-bí-mú-bál-íl-à children REL $=$ they-them-him-count-APPL

b. Q: bì-kí è-by-áá-bál-íl-w-á Kátáámbâ 8-what AUG-they-p2-count-APPL-PASS K.

A: bì-kópò byèè= by-áá-mú-bál-íl-w-à cups REL $=$ they-them-him-count-APPL 'who pl. are counting cups for him'

'it's the children who are counting them for him'

'what pl. were counted for Katamba?'

'it's cups that were counted for him'

However, there are two differences with other clefts: First, HTR does not apply to the verb in a subject cleft. Second, the REL marker now functions as a proclitic, thereby retaining the underlying length of /ba-e/ and /bi-e/ in the above examples. The cliticization of /-e/ is probably responsible for blocking HTR.

While is tempting to view HTR as a kind of out-of-focus reduction process, it seems to be associated with the lack of augment. This can be observed in the realization of embedded WH clauses. Following an affirmative main clause verb in a neutral focus sentence, a [+A(ugment)] context, there is no HTR:

(39) a. m̀̀-mànyí =ání gwè bá-bál-íl-à

'I know who (that) they are counting for'

b. m̀̀-mànyí =kí kyè bá-mú-bál-íl-à

'I know what (that) they are counting for him'

c. ̀̀-mànyí =wá gyè bá-bí-mú-bál-íl-à

'I know where (that) they are counting them for him'

d. ̀̀-mànyí =ddí lwè bá-bí-mú-bál-íl-à

I-know when that they-them-him-count-APPL

'I know when (that) they are counting them for him'

However, after a negative main clause verb, a [-A] context, HTR applies:

(40) a. sí-mányí =àní gwè bà-bàl--íl-à

'I don't know who (that) they are counting for'

b. sí-mányí = ${ }^{\downarrow}$ kí kyè bà-mù-bàl-íl-à

'I don't know what (that) they are counting for him' 
c. sí-mányí = ${ }^{\downarrow}$ wá gyè bà-bì-mù-bàl-íl-à

'I don't know where (that) they are counting for him'

d. sí-mányí = 'ddí lwè bà-bì-mù-bàl--íl-à

I.NEG-know when that they-them-him-count-APPL

'I don't know when (that) they are counting for him'

As was shown in Hyman \& Katamba (2010), HTR also optionally targets a subject relative verb whose head is [-A]:

(41) a. tú-làb-á á-bá-kázì à-bá-géénd-à 'we see the women [+A] who are

$\mathrm{H}$ L $\begin{array}{llllll}H & \mathrm{H} & \mathrm{H} & \mathrm{L}\end{array}$ going'

b. tè-tú-làb-à bà-kázì bá-géénd-à $\% \mathrm{~L} \mathrm{H} \quad \mathrm{L} \quad \mathrm{L}$

$\begin{array}{llll}\mathrm{H} & \mathrm{H} & \mathrm{H} & \mathrm{L}\end{array}$

'we don't see the women [-A] who are going'

c. tè-tú-làb-à bà-kázì bà-géénd-à $\% \mathrm{~L} \mathrm{H} \quad \mathrm{L} \quad \mathrm{L}$

$\mathrm{HL} \quad \mathrm{L}$

$\mathrm{H} \quad \mathrm{L}$

'we don't see the women [-A] who are going'

Similarly, HTR also optionally targets an object relative clause verb whose head in $[-\mathrm{A}]$ :

(42) a. tú-gùl-á é-bí-kópò byè tú-làb-á 'we buy the cups [+A] that we H L $\quad H$ L $\quad$ H L H\% see' (*tù-làb-â)

b. tè-tú-gúl-á bì-kópò byè tú-làb-á 'we don’t buy the cups [-A] that \%L H HL $\quad$ H L $\quad$ H L $\quad H \% \quad$ we see’ (< tú-làb-à + H\%)

c. tè-tú-gúl-á bì-kópò byè tù-làb-â 'we don't buy the cups [-A] that \%L H HL H L L L HL we see'

While the above treatment is brief, the HTR process is one that provides an interesting window into the syntax-phonology interface-and requires more work-in Luganda.

\section{A WH tense with its own morphology/tonology}

In this brief section we simply mention a rather specialized tense marked by an /-áa-/ prefix and a toneless -i-e final $(<*$-id-e) requires a WH element after it (Hyman \& Katamba 1990):

(43) a. w-áá-láb-y-èè =àní 'who have you seen yet?' /o-aa-lab-i-e/

b. w-áà-síb-y-éé =kí ' 'what have you tied up yet?' /o-aa-sib-i-e/ you-TNS-Sib-TNS what

$\mathrm{H}$ 
As seen, this tense is marked by the prefix /-áa-/ and the perfective ending /-i-e/. This tense is the only construction in Luganda where /-i-e/ occurs without a suffixal tone. It also cannot occur without a WH element.

\section{Summary}

In the above sections we have seen the following concerning WH questions: (i) WH questions show important differences with corresponding declaratives and yes-no questions. (ii) Subject- and non-subject WH questions show important differences. (iii) One morphological tense requires the presence of a $\mathrm{WH}$ element. We have also seen that WH questions have their own intonation which is different from both declarative and yes-no interrogative intonation. This intonation, however, only occurs when a WH element is final in the clause.

Finally, we have seen that WH questions may be expressed via different grammatical structures with the following properties: (i) WH elements may be post-verbal (non-subject), pre-verbal (subject), clefted or pseudo-clefted. (ii) When WH elements occur post-verbally, the verb has main clause morphology/tonology, as in declaratives; the WH element must however be in IAV position. (iii) A subject WH element must be preverbal; unlike declaratives, the verb must have relative clause morphology/tonology. (iv) When a nonsubject WH argument is clefted, the verb, which has relative clause morphology and tonology, may not undergo HTR-vs. the corresponding non-WH cleft, which may undergo HTR. (v) Echo questions often escape the properties of $\mathrm{WH}$ questions and more closely resemble yes-no interrogative utterances.

\section{References}

Clements, George N. (1986). Compensatory lengthening and consonant gemination in LuGanda. In: Leo Wetzels and Engin Sezer (eds). Studies in compensatory lengthening. Dordrecht: Foris, 37-77.

Hyman, Larry M. (1990). Boundary tonology and the prosodic hierarchy. In: Sharon Inkelas \& Draga Zec (eds). The phonology-syntax connection. Chicago and London: University of Chicago Press, 109-125.

Hyman, Larry M. \& Francis X. Katamba (1990a). Final vowel shortening in Luganda. Studies in African Linguistics 21, 1-59.

Hyman, Larry M. \& Francis X. Katamba (1990b). Spurious high-tone extensions in Luganda. South African Journal of African Languages 10, 142-158.

Hyman, Larry M. \& Francis X. Katamba (1993). The augment in Luganda: syntax or pragmatics?. In: Sam Mchombo (ed.). Theoretical aspects of Bantu grammar. Stanford: C.S.L.I, 209-256. 
Hyman, Larry M. \& Francis X. Katamba (2010). Tone, syntax, and prosodic domains in Luganda. In: Laura J. Downing et al (eds). Papers from the Workshop on Bantu Relative Clauses. ZAS Papers in Linguistics 53. Berlin, 69-98.

Katamba, Francis X. (1974). Aspects of the grammar of Luganda. Doctoral dissertation. University of Edinburgh.

Stevick, E. W. (1969). Pitch and duration in Ganda. Journal of African Languages 8, 1-28.

Tucker, A. N. (1962). The syllable in Luganda: a prosodic account. Journal of African Languages 1, 122-166.

Walusimbi, Livingstone (1996). Relative clauses in Luganda. Köln: Rüdiger Köppe Verlag. 